\title{
Teaching the Evolution of Morality: Status and Resources
}

\author{
Douglas Allchin
}

Published online: 8 October 2009

(C) Springer Science + Business Media, LLC 2009

\begin{abstract}
Recent studies now provide a relatively robust explanation of how moral behavior evolved, perhaps not just in humans. An analysis of current biology textbooks shows that they fail to address this critical topic fully. Here, I survey resources-books, images, and videos - that can guide educators in meeting the challenge of teaching the biology of morality.
\end{abstract}

Keywords Evolution · Morality · Social Darwinism

I fully subscribe to the judgment of those writers who maintain that of all the differences between man and the lower animals, the moral sense or conscience is by far the most important.

\section{- Charles Darwin, Descent of Man}

Study of the biology of morality has expanded substantially in recent decades - and it is still growing. Research has highlighted the social structure and cooperative behavior in insects, primates, and other animals, from vampire bats to meerkats and naked mole rats. They have analyzed human economic choices of costly helping and selfishness in many cultures and modeled games of cooperation, defection, punishment, and group choice. Anthropologists have studied political organization and norms in hunter-gatherers and other isolated cultures, while neurophysiologists have engaged new imaging technologies to identify areas of the brain active in various forms of moral thinking. The ultra-reductionism and

D. Allchin $(\bowtie)$

Program in History of Science and Technology,

University of Minnesota,

148 Tate Physics,

Minneapolis, MN 55455, USA

e-mail: allch001@umn.edu implicit promotion of competition that once dominated the field (for example, E.O. Wilson's Sociobiology and On Human Nature, and Richard Dawkins' The Selfish Gene) have, along with the rhetoric of the Cold War, yielded to more balanced perspectives and more nuanced interpretations. Scientific understanding of morality as an evolved form of behavior is now fairly robust.

Given the intellectual, cultural, and political importance of the nature of morality, a scientific perspective on the origin of moral behavior seems essential for a full, humanistic understanding of evolution. Evolution education is thus not just about interpreting patterns in fossils, mastering principles of natural selection, or appreciating some unifying theme in biology. Nor is it just about profiling the "nature of science" more effectively. It is also critically about conveying an understanding of who we are as moral beings in the context of our organic history. No introductory biology course can be considered complete without addressing the evolution of morality (Allchin 2009a). Yet, as profiled here, current textbook coverage is generally incomplete and tends to exhibit an outmoded reductionistic bias. To help remedy this deficit and foster better understanding among educators, I review here a number of books available to the general reader. These books provide general background knowledge for teachers and supplement a new textbook insert for students which profiles the basic concepts (Allchin 2009b).

\section{Current Status of Teaching Evolution of Morality}

What is currently taught about evolution of morality in biology courses? For a rough-hewn (but hopefully sufficiently conservative) analysis, I surveyed a sample of major textbooks in the US market for several benchmark concepts 
(Table 1). ${ }^{1}$ The texts were targeted at various levels: introductory college (both biology majors and non-majors) and secondary (high school) students.

Despite modest differences (due to author emphasis and style), there is a widespread consensus ${ }^{2}$ about what is relevant to address. Informative patterns are present:

1. All texts address animal behavior, including social behavior. (Not so for textbooks several decades agoand this surely reflects the tremendous expansion of research and deepening of knowledge in this area.) There is surely a context for addressing the biology of morality.

2. All texts address the innate/learned distinction, although they rarely extend it explicitly to the structure of human culture or, more particularly, to morality.

3. Nearly all acknowledge "altruism" among animals as an evolutionary puzzle and provide some sort of explanation. At the same time, most are not clear whether they intend such explanations to be relevant to interpreting human altruism: for example, where mental intent may be relevant (Sober and Wilson 1998).

4. Reductionistic bias varies, but the texts basically omit the concept of emergent properties or new levels of organization at the psychological and social levels (Holland 1998; Camazine et al. 2001; Richerson and Boyd 2005; Murphy and Brown 2007). They do not describe how social rewards or sanctions can regulate "selfish" behavior or individual "cheating"-for example, as observed in food sharing among vampire bats (Wilkinson 1984, 1990). All texts generally present a genetic explanation for cooperative or "altruistic" behavior, while also referring in some way (elsewhere) to cultural evolution. Yet, they fail to reconcile the apparent conflicts inherent in these alternative views. The bias is further reflected in the near-universal consideration of kin selection (Hamilton 1964) coupled with widespread neglect of reciprocity (Trivers 1971), although the scientific literature over the past several decades typically treats the concepts in tandem (c.f., Krebs and Davies 1993; Nowak 2006).

\footnotetext{
${ }^{1}$ This is not intended as an evaluative assessment of any specific text identified here, either as whole text or with respect to this specific topic. Rather, the relevant information is at the level of the ensemble of texts. Reflecting the aim to assess the "market," the reviewed books were the "leading" textbook from each publisher who exhibited at the 2008 meeting of the (US) National Association of Biology Teachers (as identified by each publisher's representative). Although proper sales statistics are not available, the texts by Campbell and Reece and by Miller and Levine are generally recognized anecdotally by publishing industry professionals and teachers as having the largest (indeed, dominant) market share.

${ }^{2}$ Convergence of textbooks is not uncommon in a competitive market. The coincidence of publication dates, for example, reflects synchronized cycles of edition revision.
}

5. College texts, not surprisingly, provide more depth than high school texts. At the same time, non-majors texts are more consistent than majors texts in profiling cultural evolution, or the status of human society in an evolutionary context. "Why is this material deemed less relevant for those pursuing a biology degree?" one may wonder.

6. Cautions about interpreting human behavior in the context of non-human, apparently "natural" examples, are relatively quite rare. There are no mentions of "Social Darwinism," its flaws and misleading impressions, or its status as an ideology not supported by evolutionary science (Allchin 2007a, b).

In summary, there seems to be a substantive deficit in what is being taught compared to what is currently known about the biology of morality - and what has been known for at least the past seven years (roughly two cycles for revising textbook editions) - even though much information is already available in popular formats.

\section{Prospects: A Survey of Books}

Many books on the evolution of morality are now available for the general reader. Some excel in describing the science, others in profiling the limits and cultural context of the science. A few books (by science popularizers or journalists) are less fully informed and, given their potential to mislead readers or to reinforce cultural ideologies, should be marked for receiving a more critical posture.

Perhaps the most approachable book, lucid and personable, is The Origins of Virtue (1996), by science writer Matt Ridley. He explains: "Our minds have been built by selfish genes, but they have been built to be social, trustworthy and cooperative. This is the paradox this book has tried to explain." It is an excellent guide to how scientists solve the central puzzle (setting aside the author's brief anti-government tirade in the final chapter). Comments about the scientists and their research further enrich understanding of the nature of science.

Another prime overview is Evolutionary Origins of Morality (2000), edited by Leonard Katz. This volume has hefty papers by primatologist Frans de Waal, anthropologist Christopher Boehm, philosopher-biologist duo Elliott Sober and David Sloan Wilson, and games-theorist Brian Skyrms, each summarizing their books (further profiled below). In addition to providing a healthy cross-disciplinary mix, the volume has ten commentaries on each primary paper, profiling an informative spectrum of interpretive perspectives. This book complements the earlier Biology of Morality (1978), edited by Gunther Stent, which, while the information is dated and incomplete, still serves as an effective overview of the interdisciplinary landscape. 
Table 1 Analysis of biology textbook content on evolution of morality

\begin{tabular}{|c|c|c|c|c|c|c|c|c|c|}
\hline Textbook & $\begin{array}{l}\text { Innate/ } \\
\text { learned } \\
\text { distinction }\end{array}$ & $\begin{array}{l}\text { Relevance } \\
\text { of learning } \\
\text { to morality }\end{array}$ & $\begin{array}{l}\text { Kin } \\
\text { selection }\end{array}$ & $\begin{array}{l}\text { Reciprocal } \\
\text { altruism }\end{array}$ & $\begin{array}{l}\text { Cultural } \\
\text { evolution }\end{array}$ & $\begin{array}{l}\text { Rewards/ } \\
\text { sanctions }\end{array}$ & $\begin{array}{l}\text { Nature/ } \\
\text { nurture } \\
\text { caveat }\end{array}$ & $\begin{array}{l}\text { Emergent } \\
\text { properties }\end{array}$ & $\begin{array}{l}\text { Reductionistic } \\
\text { bias }\end{array}$ \\
\hline \multicolumn{10}{|l|}{ Majors } \\
\hline Campbell et al. (2008) & $\checkmark$ & & $\checkmark$ & $\checkmark$ & $\checkmark$ & & $\checkmark$ & & \\
\hline Russell et al. (2008) ${ }^{\mathrm{a}}$ & $\checkmark$ & & $\checkmark$ & $\checkmark$ & & & $\checkmark$ & & $\checkmark$ \\
\hline Sadava et al. (2008) & $\checkmark$ & & $\checkmark$ & & $\checkmark$ & & & & \\
\hline Solomon et al. (2008) & $\checkmark$ & $\checkmark$ & $\checkmark$ & $\checkmark$ & $\checkmark$ & & & & \\
\hline Starr et al. (2009) ${ }^{\mathrm{b}}$ & $\checkmark$ & & $\checkmark$ & & & & $\checkmark$ & & $\checkmark$ \\
\hline \multicolumn{10}{|l|}{ Non-majors } \\
\hline Alters and Alters (2006) ${ }^{\mathrm{c}}$ & $\checkmark$ & & & & & & & & $\checkmark$ \\
\hline Audesirk et al. $(2008)^{\mathrm{d}}$ & $\checkmark$ & & $\checkmark$ & & $\checkmark$ & & & & $\checkmark$ \\
\hline Cain et al. (2009) & $\checkmark$ & & $\checkmark$ & & $\checkmark ?$ & & & $?$ & \\
\hline Hoefnagels $(2009)^{\mathrm{e}}$ & $\checkmark$ & & $\checkmark$ & & $\checkmark$ & & & & \\
\hline Mader $(2009)^{\mathrm{f}}$ & $\checkmark$ & & $\checkmark$ & $\checkmark$ & $\checkmark$ & & & & $\checkmark$ \\
\hline Pruitt and Underwood (2006) & $\checkmark$ & & $\checkmark$ & & $\checkmark$ & & & & \\
\hline \multicolumn{10}{|l|}{ Secondary } \\
\hline BSCS (2006) & $\checkmark$ & & $\checkmark$ & & & & & & $\sqrt{ } ?$ \\
\hline De Salle and Heithaus $(2008)^{\mathrm{g}}$ & $\checkmark$ & & & & & & $\checkmark$ & & $\checkmark$ \\
\hline Postlethwait and Hopson (2009) & $\checkmark$ & & $\checkmark$ & & & & & & \\
\hline Miller and Levine (2008) & $\checkmark$ & & $\checkmark$ & & & & & & \\
\hline
\end{tabular}

${ }^{\text {a }}$ Presents child abuse in reconstituted human families as biological

${ }^{\mathrm{b}}$ Emphasizes reproductive success; chapter opens with "My Pheremones Made Me Do It" about honeybees, followed by section on "How Genes Affect Behavior"

${ }^{\mathrm{c}}$ Emphasizes reproductive fitness; profiles evolutionary psychology; characterizes social behavior as "a form of communication"

${ }^{\mathrm{d}}$ Emphasizes individual cases more than concepts

${ }^{\mathrm{e}}$ Opens chapter with examples of risk-taking helping behavior

${ }^{\mathrm{f}}$ Opens with case of naked mole rats to frame questions

${ }^{\mathrm{g}}$ Emphasizes reproductive success; characterizes cooperation as mutual selfishness

Frans de Waal's work is presented more fully in Good Natured: The Origin of Right and Wrong in Primates and Other Animals (1996). It is filled with vivid-and instructive - anecdotes of primate behavior, especially well suited for classrooms with a non-academic tone. De Waal focuses thematically on features that contribute to a fully developed moral system: sympathy, rank and order, quid pro quo (tit for tat), and getting along (such as reconciliation), elements that he brings together in a final commentary. In The Ape and the Sushi Master (2001), he expands his focus to address features of primate and animal culture, aiming to erode assumptions that dichotomize nature and (exclusively human) culture. Later, in Primates and Philosophers (2006), de Waal returns to interdisciplinary discourse, taking issue in particular with the notion that human morality is only a thin "veneer" covering a selfish core. He emphasizes the deeply embedded (primate) emotions of empathy, consolation, reciprocity, and fairness. (The contributions from his commentators-Philip Kitcher, Peter Singer, Christine Korsgaard, and Robert Wright-however, are not deeply informative.)

Krebs and Davies' An Introduction to Behavioral Ecology (1993) is an advanced text that is now partly dated conceptually but is still valuable in summarizing many concrete examples.

In Hierarchy in the Forest (1999), Christopher Boehm analyses egalitarian societies and the links between morality and political organization. He compares modern humans with their ancestors and closest primate relatives. Boehm claims that under appropriate conditions, "a large, ad hoc, community-wide political coalition serves as watchdog over individual behaviors that could lead to victimization of others, or to conflict within the group" (Katz 2000, p. 80). He profiles the politics of chimps, hunter-gatherers, tribesmen, and other hominoids and surveys the preadaptations that empower moral communities, such as effective 
communication skills. He also underscores the role of the early human social environment in shaping further biological evolution. This highlights the importance of understanding levels of organization in biology - the genetic, the organismal, the psychological, and the social-and how they interact, with regulation from the "top-down" as much as by development from the "bottom-up." The framework of cultural evolution (along with its potential for shaping biological traits) is also addressed extensively in Peter Richerson and Richard Boyd's Not By Genes Alone (2005). They sketch how behavior can be transmitted culturally, highlighting the ability to mimic, or copy, in lieu of learning individually. At the same time, they appeal broadly (and often uncritically) to diffuse group selection, emphasizing ingroup cohesion and out-group conflict in shaping behavior.

The distinction between levels of organization and their relevance for moral behavior is also explored in Sober and Wilson's Do Unto Others (1998). They distinguish, in particular, evolutionary altruism (at the genetic level) and psychological altruism (at a mental, intentional level). They, too, support the notion of group selection but without fully considering the role of social selection and sanctioning, which have become more prominent since they published their book.

A major area of investigation has been simulations of various evolutionary strategies to determine which are stable. Cheaters can disrupt a system of cooperators, for example, proliferate, and ultimately replace the cooperators. Brian Skyrms presents the results of many such models in The Evolution of the Social Contract (1996). His work echoes the landmark 1984 Evolution of Cooperation, by Robert Axelrod. These works might be useful in inspiring students with computer programming skills to set up some simple simulations of their own. Alternatively, a creative teacher might find in them an occasion to develop student activities wherein students play games in successive rounds based on choosing to "cooperate" or "defect." Such activities might provide first-hand experience exploring various factors or assumptions, such as the ability to "punish" non-cooperators or to opt out of the system (Novak 2006; Güreck et al. 2006; Hauert et al. 2007).

The modern reader will still find much of value in Darwin's original Descent of Man (1871). Darwin's theory of the origin of the moral sense, or the feeling of duty to help one's fellows (Chapter 3), drew on four elements: (1) social instincts, a product of a social species able to provide mutual benefit; (2) memory, a foundation for reflection, remorse, and conscience; (3) language, allowing each organism to communicate its needs more effectively; and (4) habit, the product of learning, which will generate immediate, unreflective responses. Darwin's work has many flaws by modern standards. Yet some comments also seem remarkably prescient-for example, his hesitant speculations about group selection, considerations of punishment, or the role of social selection in fitness. It is fascinating to see how Darwin articulated the first informed approach to morality from the unique perspective of natural history.

In his "sequel" work, The Expression of Emotions (1872), Darwin delved more fully into the roots of the third element, communication, namely, how did organisms exhibit externally their internal emotions in such a way that others could respond to them, even without language? Darwin considered body postures and the muscles involved in various facial expressions, noting, for example, how their opposite extremes were associated with contrary emotions. His work drew in part on studies by Ernest Duchenne, who photographed subjects when specific muscles had been activated with electrodes. It is a landmark work in showing how mental states may be investigating physiologicallystill accessible and provocative to the general reader.

Readers with deeper historical interests may consult Robert Richards' authoritative (and award-winning) Darwin and the Emergence of Evolutionary Theories of Mind and Behavior (1987), which profiles developments in psychology, including moral thinking, in the nineteenth century. (The volume is valuable mostly for historians, in tracing Darwin's thinking, rather than for educators, who may be looking for a prospective conceptual trajectory that might engage modern students, say.) Richards' history of science is extended into the history of philosophy in Biology and the Foundations of Ethics (1999), edited by Jane Maienschein and Michael Ruse. The contributors are all distinguished scholars, but the volume as a whole is not well unified.

Readers with strong philosophical interests may be especially concerned about evolutionary interpretations of intention, agency, or free will (at the psychological level). These are addressed in several books, none yet synoptic or comprehensive, however-or simple. In The Evolution of Agency and Other Essays (2001), Kim Sterelny addresses the problem of intention. He argues, first, that there was an important shift from neural systems that respond to single stimuli to those that integrate multiple environmental cues. $\mathrm{He}$ then articulates the role of preference, emerging from behavioral plasticity (afforded by learning). The result: desires, in organisms that can truly represent their environment internally (and not "merely" respond to it). Bruce Waller looks at the implications for moral philosophy in The Natural Selection of Autonomy (1998). He claims that we share the domain of autonomy and morality with other animals and that doing so requires major revisions in our conceptions of moral objectivity and moral responsibility. In The Biology and Psychology of Moral Agency (1998), William Roffschaffer likewise uses evolutionary knowledge to reassess the philosophical concept of moral agency, leading to a multi-leveled approach reflecting evolutionary history. Educators take note: these three books are not for the philosophically squeamish. 
A final set of books earn mention because they help frame the limits of evolutionary approaches to morality and culture. They are mostly cautionary in tone. For example, many persons imagine that evolution might ultimately resolve the question of "human nature" or what moral principles "really" are (or should be). A healthy check is provided both by Paul Farber's The Temptations of Evolutionary Ethics (1994) and by Michael Bradie's The Secret Chain (1994). Each discusses how trying to justify particular human values from the facts of evolution fails. Farber's book is more historical, Bradie's more philosophical. Both underscore the problem of naturalizing cultural ideologies - that is, ascribing one's own cultural beliefs to nature. Richard Joyce echoes similar sentiments in The Evolution of Morality (2006), using more philosophical prose (and correspondingly less biological rigor); he concludes, characteristically, "we should reject or modify any theory that would render us epistemic slaves to the baby-bearing capacities of our ancestors" (p. 219).

One may note the absence of books about sociobiology cited here. While these books inspired much research, their relevance is now limited, especially in interpreting human morality, as opposed to animal sociality or cooperation based on kin selection. Genetic explanations typically fall short in explaining psychological or social-level phenomena fully. The sociobiology fad is instructive historically, however. The episode illustrates the power of persistent but misleading assumptions about biological determinism. The errors of this doctrine are profiled, along with their political context, in Richard Lewontin's Biology as Ideology (1993), Stephen Rose's Lifelines: Life Beyond the Gene (1997), and earlier in Not in Our Genes (1984), co-authored by these two and Leon Kamin.

Caution may extend also to the current wave of evolutionary psychology. Robert Richardson's Evolutionary Psychology as Maladapted Psychology (2007) is a good overview of the methodological problems that generate many hasty, unjustified claims. Considerable attention has also been devoted to the nineteenth century case of Phineas Gage, who lost a large section of his brain in a railway repair accident but survived, albeit with dramatically altered moral behavior. His case is examined in depth by Malcolm Macmillan in An Odd Kind of Fame: Stories of Phineas Gage (2000). Macmillan shows how the facts of the case have been repeatedly refashioned and reinterpreted, sometimes in contradictory ways, to fit different scientific ideals. Ultimately, few claims fit with what little is documented historically (including recent high-profile claims by neurophysiologist Antonio Damasio). The report by the original attending physician, John Harlow, is reproduced for reference. Ultimately, the case presents a fascinating and sobering lesson about the role of preconceptions in science and the potential for error-valuable for understanding, and teaching about, the nature of science (Allchin 1995, 2008). We are well advised to think critically and skeptically when biologists address culture.

Finally, readers eager to venture deeper into the recent scientific literature may consult the online text by Allchin (2009a) and its bibliography. Recent sources may be needed especially for addressing findings in neurophysiology, shifting views on the roles of reason versus emotion, and debates about intentionality and deception in non-human animals. Not addressed here are other possibly relevant books on child psychology (moral development), social psychology, economic decision-making, or the general theme of emergence, systems theory, and anti-reductionism.

\section{Books to Avoid}

Ideally, one may like to imagine that everything written on the topic of evolution and morality is informative. Alas, the seductive drama of the subject has attracted many authors not well qualified, either biologically or philosophically(!). Blind enthusiasm for sociobiology and pop evolutionary psychology has spawned many books that play on plausibility but are uncritical and misleading. Sadly, then, I alert readers to a few books that are widely encountered but earn negative recognition.

Perhaps the most disturbing is The Moral Animal (1994), by Robert Wright, who offers the credentials of a journalist, although based on the book's claims one might surmise a rather ambitious one. Human behavior is largely reduced to competition and career moves. There is no sensitivity to social context (as in Boehm's book, say). The overall "message" is not much different from the discredited doctrines of Herbert Spencer, warmed over with modern jargon.

Nancy Etcoff's Survival of the Prettiest (1999), ironically subtitled The Science of Beauty, is also grossly misleading. It is a confused melange that tries to portray as instinct a will to seduction, a desire to be sexy, and universal norms of attractiveness. Add to this a dash of feminism and an implicit stigma for those perceived as ugly, and you have quite a fine example of culturally tainted pseudoscience. Those wishing a primer on sexual or social selection will be better rewarded reading Volume 2 of Darwin's Descent of Man.

Jared Diamond's The Third Chimpanzee also exhibits overt cultural bias, promoting such unwarranted surmises as expensive dates being about reproductive fitness.

Several authors succumb to the temptations that Farber cautions against. Larry Arnhart in Darwinian Natural Right attempts to claim that biological universals are "natural" and, therefore, desirable and even justified. However, frequency does not indicate value. The same error appears in Michael McCullough's Beyond Revenge (2008), although it includes informative social psychology, outside 
an evolutionary context. Many essays in Evolutionary Ethics and Contemporary Biology (2006; edited by Boniolo Giovanni and Gabriele De Anna) also suffer from such aspirations as well. In Created from Animals: The Moral Implications of Darwinism (1990), James Rachels suggests that our moral duties are shaped by our relationship to other species, as shown by evolution. His claims are provocative and warrant consideration. However, the claim is really founded on an assumed value of kinship, not the facts of Darwinism. Keeping such distinctions clear is important, and the casual uncritical reader may easily slip into error.

\section{Prospects: Images and Videos}

As noted earlier, the basic concepts have been described and structured for classroom use in a textbook-style essay, "The Evolution of Morality" (Allchin 2009b). However, for modern classroom presentations, visuals also seem essential. Images have been collected in an online image bank (Allchin 2009c), cleared for copyright permission in educational contexts: http://EvolutionOfMorality.net/images/. The images are organized by theme, key concept, and content, such as "moral systems (sociality and communication) | network reciprocity | vampire bats." Each image comes with two instructional captions: one didactic, one for inquirymode teaching. The images are also integrated into a complete text for student use, as well as organized in a web-browser-based image-only presentation for classroom instruction.

Videos are also helpful in presenting samples of relevant behavior. Online samples relevant to the evolution of morality have been listed at (Allchin 2009d): http:// EvolutionOfMorality.net/videos.htm. This includes, for example, links to videos of the 1996 case at Chicago's Brookfield Zoo of a gorilla (Bintijua) handling a child that had fallen into its enclosure and a similar incident at the Jersey Zoo in England. Others are observational data from recent scientific research.

\section{Prospects: Strategies}

The challenge for teachers, ultimately, is to distill and organize all this information - and present it simply and coherently for students. The problem seems amplified by contrasting approaches to morality among philosophers: consequentialism, on the one hand, and deontology, on the other (at least). A framework incorporating these contrasts in a biological context was presented earlier (Allchin 1999, 2006) has recently been updated. The approach is based on first clarifying the different levels of biological explanations and the philosophical traditions whose concepts are closely allied with each:

\begin{tabular}{|c|c|c|}
\hline Behavior & Moral Philosophy & Biological Science \\
\hline Moral acts & Consequentialism & $\begin{array}{l}\text { Instinct and behavioral } \\
\text { genetics }\end{array}$ \\
\hline Moral motives or intent & Deontology & $\begin{array}{l}\text { Psychology and } \\
\text { neurophysiology }\end{array}$ \\
\hline Moral systems & Social contract & $\begin{array}{l}\text { Sociality and } \\
\text { communication }\end{array}$ \\
\hline
\end{tabular}

Within this framework, one may articulate the basic biological concepts, such as inclusive fitness and kin selection; reciprocity; neurological structure and function; open behavioral programs, learning, and behavioral plasticity; tragedy of the commons; emergence; sanctions and strong reciprocity; network reciprocity; and image scoring (reputation) and indirect reciprocity. The threefold structure helps distinguish the different levels of causality for these concepts - genetic/evolutionary, psychological, and socialand shows how their effects must be integrated.

In the nineteenth century, Darwin could only speculate about and sketch the evolution of moral acts, moral feelings, and moral systems. Now, however, we have a wealth of studies of human, primate, and other animal behavior, and of neurophysiology and Paleolithic cultures that are all coalescing into robust explanations about our heritage as moral organisms. Now, on the occasion of Darwin's bicentennial, we are ready to teach a deeper understanding of the biology of morality.

\section{References}

Allchin D. How not to teach history in science. In: Finley F, Allchin D, Rhees D, Fifield S, editors. Proceedings, Third International History, Philosophy and Science Teaching Conference, Minneapolis, MN. 1995;1:13-22.

Allchin D. Teaching Darwin seriously: addressing evolution and ethics. Am Biol Teach. 1999;61:350-5.

Allchin D. Evolution and the biology of morality. Rep Natl Cent Sci Educ. 2006;25(3-4):31-4.

Allchin D. Social un-Darwinism. Am Biol Teach. 2007a;69:113-5.

Allchin D. A more fitting analogy. Am Biol Teach. 2007b;69:174-6. doi:10.1662/0002-7685(2007)69[174:AMFA]2.0.CO;2.

Allchin D. Nobel ideals and noble errors. Am Biol Teach. 2008;70:38992. doi:10.1662/0002-7685(2008)70[389:FTP]2.0.CO;2.

Allchin D. Why we need to teach the evolution of morality. Evolution: education and outreach. 2009a. doi:10.1007/s12052-009-0172-x.

Allchin D. The evolution of morality. Evolution: education and outreach. 2009b. doi:10.1007/s12052-009-0167-7.

Allchin D. The evolution of morality: image bank. Minneapolis: SHiPS Resource Center. 2009c. http://EvolutionOfMorality.net/ images/. Accessed 18 May 2009.

Allchin D. Teaching the evolution of morality: videos. Minneapolis: SHiPS Resource Center. 2009d. http://EvolutionOfMorality.net/ videos.htm. Accessed 18 May 2009. 
Camazine S, Deneubourg JL, Franks NR, Sneyd J, Theraulaz G, Bonabeau E. Self-organization in biological systems. Princeton: Princeton University Press; 2001.

Güreck Ö, Irlenbusch B, Rockenbach B. The competitive advantage of sanctioning institutions. Science. 2006;312:108-11. doi:10.1126/science. 1123633 .

Hamilton WD. The genetical evolution of social behavior. J Theor Biol. 1964;7:1-52. doi:10.1016/0022-5193(64)90038-4.

Hauert C, Traulsen A, Brandt H, Nowak MA, Sigmund K. Via freedom to coercion: the emergence of costly punishment. Science. 2007;316:1905-7. doi:10.1126/science.1141588.

Holland JH. Emergence: from chaos to order. Cambridge: Perseus; 1998.

Krebs JR, Davies NB. On selfishness and altruism. An introduction to behavioural ecology. Oxford: Blackwell Scientific; 1993. p. 265-90.

Murphy N, Brown WS. Did my neurons make me do it? Philosophical and neurobiological perspectives on moral responsibility and free will. Oxford: Oxford University Press; 2007.

Nowak MA. Five rules for the evolution of cooperation. Science. 2006;314:1560-3. doi:10.1126/science.1133755.

Trivers RL. The evolution of reciprocal altruism. Q Rev Biol. 1971;46:35-57. doi:10.1086/406755.

Wilkinson GS. Reciprocal food sharing in the vampire bat. Nature. 1984;308:181-4. doi:10.1038/308181a0.

Wilkinson GS. Food sharing in vampire bats. Sci Am. 1990;262:76-82 (Feb).

\section{Textbooks Surveyed}

Alters S, Alters B. Biology: understanding life. New York: Wiley; 2006. Audesirk T, Audesirk G, Byers BE. Biology: life on earth. 8th ed. Upper Saddle River: Pearson; 2008.

BSCS. BSCS Biology: an ecological approach ["green version"]. 10th ed. Dubuque: Kendall Hunt; 2006.

Cain ML, Singh-Cundy A, Yoon C. Discover biology. 4th ed. New York: W.W. Norton; 2009.

Campbell N, Reece J. Biology. 8th ed. Upper Saddle River: Pearson; 2008. De Salle R, Heithaus MR. Biology. Orlando: Holt, Rinehart, Winston; 2008.

Hoefnagels M. Biology: concepts and investigations. Boston: McGraw Hill; 2009.

Mader SS. Concepts of biology. Boston: McGraw Hill; 2009.

Miller K, Levine J. Biology. Lebanon: Prentice Hall; 2008.

Postlethwait JH, Hopson JL. Biology. Orlando: Holt, Rinehart, Winston; 2009

Pruitt NL, Underwood LS. BioInquiry. Hoboken: Wiley; 2006.

Russell PJ, Wolfe SL, Hertz PE, Starr C, McMillan B. Biology: the dynamic science. Belmon: Brooks/Cole; 2008.

Sadava D, Heller HC, Orians GH, Purves WK, Hillis DM. Life: the science of biology. 8th ed. Sunderland: Sinauer Associates; 2008.

Solomon EP, Berg LR, Martin DW. Biology. 8th ed. Belmont: Thomson; 2008.

Starr C, Taggert R, Everts C, Starr L. Unity and diversity of life. 12th ed. Belmont: Brooks/Cole; 2009.

\section{Books Reviewed}

Axelrod R. The evolution of cooperation. New York: Basic Books; 1984. ISBN 139780465005642
Boehm C. Hierarchy in the forest: the evolution of egalitarian behavior. Cambridge: Harvard University Press; 1999. ISBN 0674-39031-8.

Bradie M. The secret chain. Albany: State University of New York Press; 1994. ISBN 139780791421062.

Darwin C. The descent of man. London: John Murray; 1871. URL: darwinonline.ac.uk.

Darwin C. The expression of the emotions in man and animals. Chicago, IL: University of Chicago Press; 1872/1965. URL: darwinonline.ac.uk.

de Waal F. Good natured: the origins of right and wrong in humans and other animals. Cambridge: Harvard University Press; 1996. ISBN 0-674-35660-8. Pb. 139780674356610.

de Waal F. The ape and the sushi master. New York: Basic Books; 2001. ISBN 0-465-04176-0.

de Waal F. Primates and philosophers: how morality evolved. Princeton: Princeton University Press; 2006. ISBN 139780691141299.

Farber P. The temptations of evolutionary ethics. Berkeley: University of California Press; 1994. ISBN 0-520-21369-6.

Joyce R. The evolution of morality. Cambridge: MIT Press; 2006. ISBN 139780262600729.

Katz LD, editor. Evolutionary origins of morality: cross-disciplinary perspectives. Exeter: Imprint Academic; 2000. ISBN 090784507X.

Lewontin RC. Biology as ideology: the doctrine of DNA. New York: Harper Collins; 1993. ISBN 139780060975197.

Lewontin RC, Rose S, Kamin LJ. Not in our genes. New York: Pantheon Books; 1984. ISBN 394-72888-2.

Macmillan M. An odd kind of fame: stories of Phineas Gage. Cambridge: MIT Press; 2000. ISBN 139780262632591.

Maienschein J, Ruse M. Biology and the foundation of ethics. Cambridge: Cambridge University Press; 1999. ISBN 13 9780521559232.

McCullough M. Beyond revenge: the evolution of the forgiveness instinct. San Francisco: Bossey-Jass; 2008.

Richards R. Darwin and the emergence of evolutionary theories of mind and behavior. Chicago: University of Chicago Press; 1987. ISBN 139780226712000 .

Richardson RC. Evolutionary psychology as maladapted psychology. Cambridge: Cambridge University Press; 2007. ISBN 13 9780262182607.

Richerson PJ, Boyd R. Not by genes alone: how culture transformed human evolution. Chicago: University of Chicago Press; 2005. ISBN 139780226712123.

Ridley M. The origins of virtue. New York: Penquin; 1996. ISBN 014-026445-0.

Rose S. Lifelines: life beyond the gene. Oxford: Oxford University Press; 1997. ISBN 139780195150391.

Rottschaefer WA. The biology and psychology of moral agency. Cambridge: Cambridge University Press; 1998. ISBN 13 9780521592659.

Skyrms B. Evolution of the social contract. Cambridge: Cambridge University Press; 1996. ISBN 139780521555838.

Sober E, Wilson DS. Unto others: the evolution and psychology of unselfish behavior. Cambridge: Harvard University Press; 1998. ISBN 0-674-93046-0.

Stent GS, editor. Morality as a biological phenomenon. Berkeley: University of California Press; 1978. ISBN 0-520-04029-5.

Sterelny K. The evolution of agency and other essays. Cambridge: Cambridge University Press; 2001.

Waller B. The natural selection of autonomy. Albany: State University of New York Press; 1998. ISBN 139780791438206. 